\author{
市 川 創 作 \\ 筑波大学 応用生物化学系 函 305 茨城県つくば市天王台 1-1-1
}

\title{
Extraction of Protein Using Reversed Micelles
}

\author{
Sosaku Ichikawa \\ Institute of Applied Biochemistry, University of Tsukuba \\ 1-1-1 Tennodai, Tsukuba, Ibaraki 305, Japan
}

The present paper reviews the reversed micellar extraction of protein on the basis of the author's research work on the occasion to be accorded the 1997 young investigator's award by the Membrane Society of Japan. The extraction of protein using AOT (di-2-ethylhexyl sodium sulfosuccinate)/isooctane reversed micellar system was investigated from the viewpoint of the solubilization of protein and water by amphiphilic molecules. The minimal AOT concentration required for $100 \%$ forward extraction of protein was found. At the minimal AOT concentration, the hydrophilic surroundings, i.e., the molar ratio of water to extracted protein in the organic phase, were independent of the protein concentration. The hydrophilic surroundings were related with Fisher's polarity ratio as an index of the hydrophobicity of protein. Using this relation, a procedure to estimate the sufficient AOT concentration for the protein extraction was proposed. In the cases of cytochrome $c$ and lysozyme extraction, the water concentration was larger than that in the protein-free system in spite of the same AOT concentration. On the contrary, in the case of ribonuclease A, this large water uptake was not observed. These differences of water uptake were discussed in relation to the location of the protein in the AOT reversed micelles. The forward extraction was accompanied by a conformational change of protein, whereas the backward extracted protein consequently refolded in the native conformation in the aqueous phase. Therefore, the relative reactivity of recovered cytochrome $c$ and ribonuclease A after forward and backward extractions showed almost $100 \%$. The recovered activity yield showed a maximum with respect to AOT concentration because of the combined effect of both decreases in forward and backward extraction yields at low and high AOT concentrations, respectively.

Key words : reversed micelles/extraction/amphiphilic molecule/protein/solubilizing water/activity yield 


\section{1. はじめに}

逆ミセルは，ある種の両親媒性分子を炭化水素 などの有機溶媒に添加した際に自発的に形成され る分子集合体である (Fig. 1). その内側には，ウ オーター・プールと呼ばれる数ナノメートルの微 小な水相を保持することができる. この逆ミセル により, 本来非極性の有機溶媒には溶解しないア ミノ酸やペプチド, タンパク質などの生体関連物 質が可溶化される.この特性を利用して抽出分離 を行う操作が逆ミセル抽出法である ${ }^{1)}$.

逆ミセルを利用したタンパク質抽出のプロセス を Fig. 1 に示した. 水溶液中の目的タンパク質 は, 逆ミセルを含む有機相と接触させることによ り正抽出される. 逆ミセル有機相を分相後, 新た な水相と接触させることで, 目的の夕ンパク質が 水相に逆抽出, 回収される. 逆ミセル有機相は分 相され, 正抽出に再利用される. 水相の $\mathrm{pH}$ や塩 濃度を調整することで選択的な正・逆抽出を行う ことができる. 本分離法を巨視的に捉えると，従 来の液一液抽出操作と同様の特徵を持ち, 簡便な 装置で連続的な操作が可能であるため，培養液な ど大容量の水溶液を対象とするバイオセパレー ション技術としての利用が期待されている.また， 抽出の機構を微視的に捉えると, タンパク質が両 親媒性分子, および, 水分子と共に自己組織化し て分子集合体を形成する挙動であり，分子間相互 作用により機能性を有する分子集合体が形成する 現象として興味深い。

本研究では，この逆ミセルを利用した新規な夕 ンパク質抽出法の基礎的研究として, タンパク質 の正抽出と逆抽出, および活性回収に対する両親 媒性分子や塩の濃度, $\mathrm{pH}$, 温度といった操作因子 の影響を定量的に評価し, 効率的な抽出条件を設 定する指針を示した。本稿では, タンパク質の抽 出挙動に対する両親媒性分子濃度の影響とその可 溶化状態を中心に記してみたい。

\section{2. タンパク質の正抽出に対する両親媒性 分子濃度の影響}

逆ミセル抽出法において, 両親媒性分子は, 逆 ミセルの形成に必要不可欠な成分であり，その濃 度がタンパク質の抽出挙動に及ぼす影響を検討す ることは重要である. そこで, 両親媒性分子とし てジ（2-エチルヘキシル）スルホコハク酸ナトリ ウム (登録商標名 Aerosol OT; 以降 AOT と略 記する), 有機溶媒としてイソオクタンを用いた 逆ミセル系を用い, モデルタンパク質シトクロム $c$ の正抽出挙動を実験的に検討した.

シトクロム $c$ の正抽出率に対する両親媒性分子 AOT 濃度の影響を Fig. 2 に示した. 正抽出率 は AOT 濃度の増加に伴って増大し, ある AOT 濃度以上で $100 \%$ の正抽出率を示した。この初期 小相中のタンパク質を $100 \%$ 正抽出するために最 小限度必要な AOT の濃度を Minimal AOT 濃 度とした ${ }^{2)}$. この濃度は, 効率的な正抽出操作を 行うための, 両親媒性分子の濃度設定の指標とし て有用である. シトクロム $c$ と同程度の分子量を 持つタンパク質, リゾチームやリボヌクレアーゼ A を正抽出した場合にもMinimal AOT 濃度の 存在が確認された ${ }^{3)}$. その結果, AOTを用いた タンパク質の逆ミセル抽出においては, Minimal AOT 濃度が存在し,この条件では抽出・可 溶化機構の一般的な背景が存在すると考え,この 条件における可溶化状態について検討を行った.

\section{Minimal AOT 濃度におけるタンパク 質と水の可溶化挙動}

Minimal AOT 濃度の条件において逆ミセル 有機相中に正抽出されたシトクロム $c$ と水の濃度 の関係を Fig. 3 に示した. シトクロム $c$ と水の 濃度は比例関係を示し, Minimal AOT 濃度の 条件では, シトクロム $c$ や AOT の濃度によらず, シトクロム $c$ と水分子とが一定の比率で存在して いることがわかった ${ }^{2)}$. Fig. 3 の傾きは, シトク 口ム $c 1$ 分子に対して平均的に存在する水分子の 数を表わすと考えられる. そこで, この傾きを夕 ンパク質の正抽出・可溶化に必要な親水的環境 (Hydrophilic Surroundings ; H.S. と略記す る）と呼ぶことにした。 


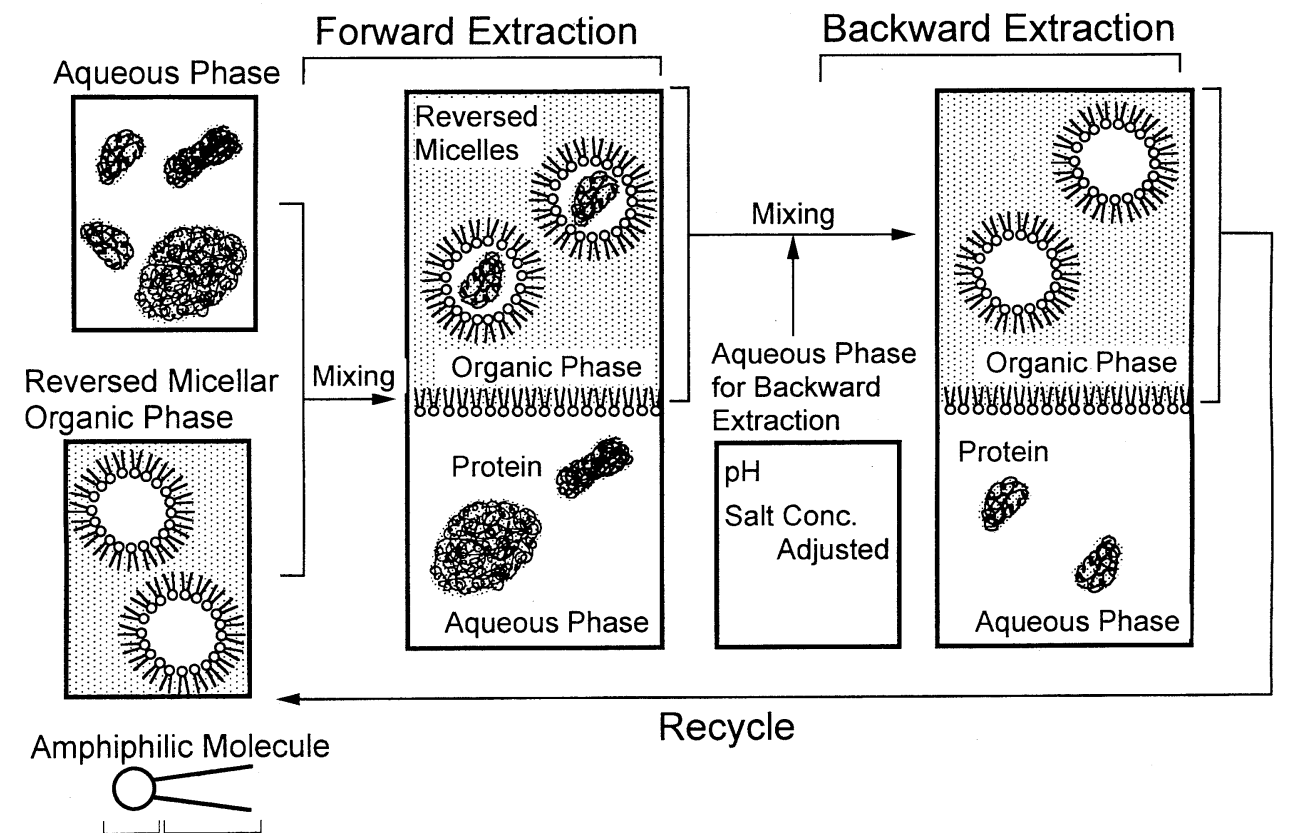

Hydrophilic Hydrophobic

Fig. 1 Extraction process of protein using reversed micelles.

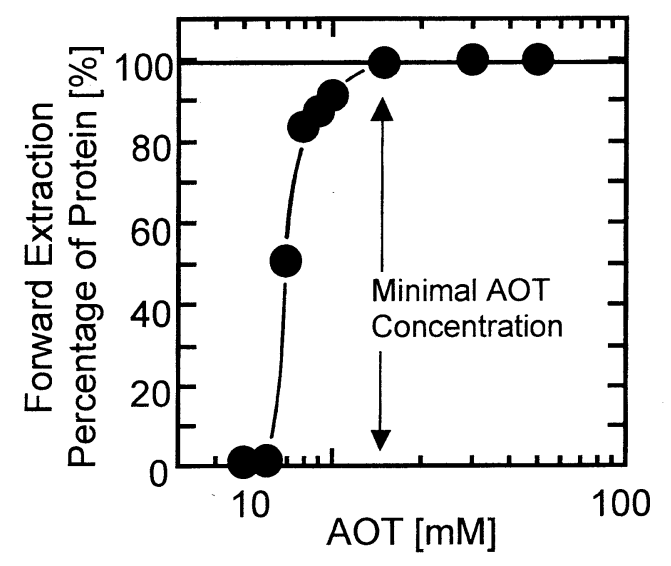

Fig. 2 Effect of AOT concentration on the forward extraction percentage of $\mathrm{cy}^{-}$ tochrome $c$. (cytochrome $c 7.8 \times 10^{-5}$ $\mathrm{M}, \mathrm{KCl} 0.1 \mathrm{M}, \mathrm{pH} 7 \sim 8$ )

Minimal AOT 濃度の条件でリゾチームやリ ボヌクレアーゼ A を正抽出した場合にも, 逆ミ セル有機相中にタンパク質と水分子とが一定の比 率で存在していることがわかり，それぞれの

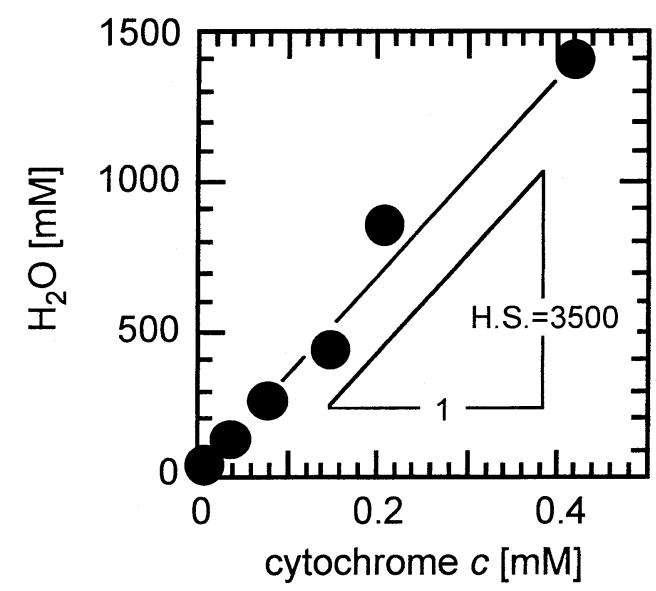

Fig. 3 Relationship between water and protein concentrations at the minimal AOT condition.

H.S. が求められた ${ }^{3)}$ 。この結果は, 非極性の有 機溶媒には溶解しない夕ンパク質が, 逆ミセル有 機相に正抽出・可溶化されるためには, 有機相に 水分子による親水的な環境の形成が必要であるこ 


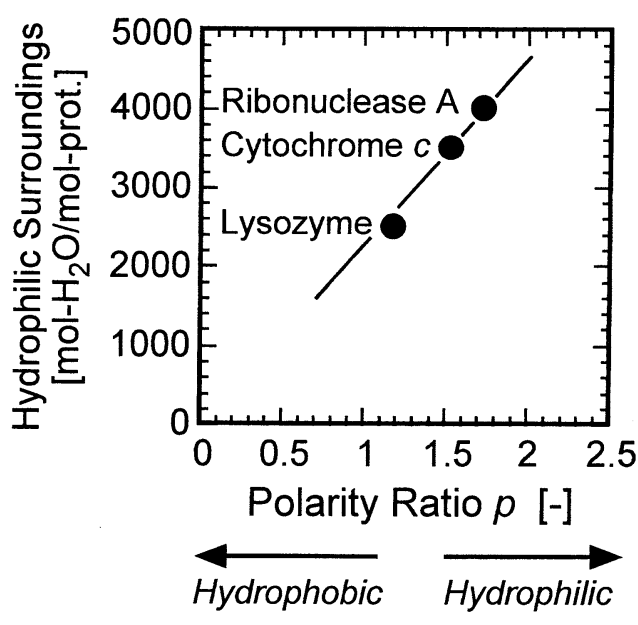

Fig. 4 Relationship between the hydrophilic surroundings required for the solubilization of protein and the polarity $\mathrm{ra}^{-}$ tio, $p$, as an index of the hydrophobicity of protein.

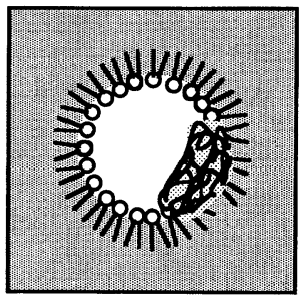

(a)

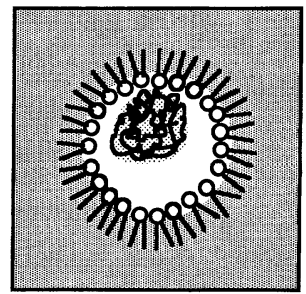

(b)
Fig. 6 A schematic representation of the location of protein solubilizing in AOT reversed micelles.

(a) in the interfacial area of AOT layer, (b) in water pool

とを示唆している.

各タンパク質の正抽出・可溶化に必要な H.S. は，タンパク質の疎水性一親水性の程度と関係す ると考えられる. その指標は種々提案されている が, この系では Fisher ${ }^{4)}$ の提案した polarity ratio（ $p$ 值）と各タンパク質の H.S. が Fig. 4 に示した様に，実験の範囲で良好な相関を示すこ とがわかった ${ }^{3)} . p$ 值は，(非極性残基体積の総 和）に対する「極性残基の体積の総和」の比で定 義され，親水性の高いタンパク質ほど大きな值を

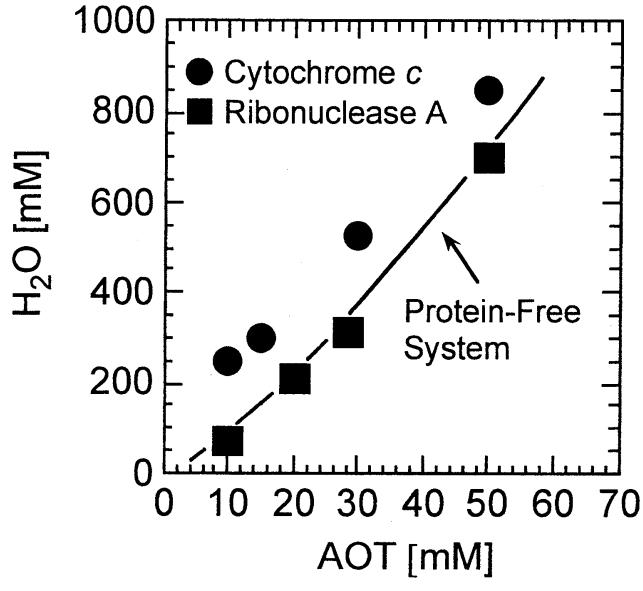

Fig. 5 Water concentration in the reversed micellar organic phase immediately after the forward extraction of protein.

示す. Fig. 4 の相関は, 親水性の高いタンパク質 ほど，逆ミセル有機相中に，正抽出・可溶化のた めの水分子が多く必要であることを示している.

タンパク質の疎水性一親水性の指標と H.S. と の一般的な相関が得られると, タンパク質の正抽 出に必要な両親媒性分子 AOT の濃度を推算する ことができる，すなわち，目的とするタンパク質 の疎水性一親水性の指標から, 得られた相関を用 いて親水的環境 H.S. を求め, 可溶化に必要な逆 ミセル有機相中の水濃度を求める。AOT 濃度と 有機相水濃度の相関は求められており, これより 正抽出に必要な AOT 濃度が推算できる.

\section{4. タンパク質の可溶化状態}

タンパク質を正抽出・可溶化した直後の逆ミセ ル有機相の水濃度と, タンパク質を含まない逆ミ セル有機相の飽和水濃度を Fig.5 に示した ${ }^{5)}$. シトクロム $c$ を抽出した場合, 飽和水濃度より多 くの水が可溶化されていることがわかる，また， リゾチームを正抽出した場合にも，シトクロム $c$ 之同様に過剩な水の可溶化が観察された ${ }^{3)}$.一方, リボヌクレアーゼ A を正抽出した場合，過剰な 水の可溶化は測定されなかった (Fig.5). 


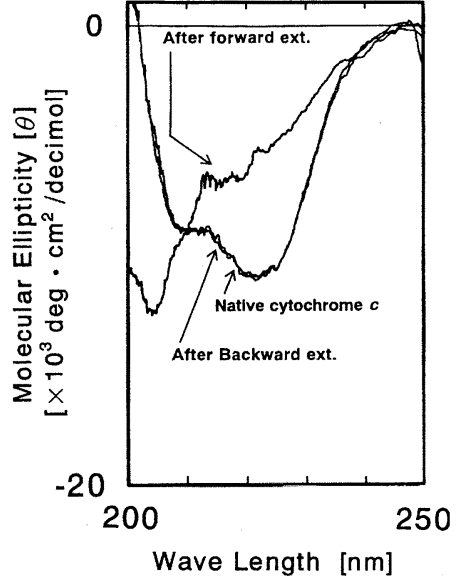

Fig. 7 Circular dichroism spectra of cytochrome $c$ in aqueous and reversed micellar organic phases.

これらタンパク質の正抽出に伴う水分子の可溶 化挙動は, AOT 逆ミセル中でのタンパク質の可 溶化位置と関連付けて考察することができる. 逆 ミセルのウオーター・プールと有機溶媒の界面に は, 両親媒性分子 AOT により分子膜が形成され ている. シトクロム $c$ とリゾチーム分子の一部は, この AOT の分子膜に入り込んだ状態で抽出され ることで, ウオーター・プールと有機溶媒との界 面積を拡大し, 過剩な水の可溶化を促したと考え られる (Fig.6 (a) $)^{5)}$. シトクロム $c$ の可溶化に ついては,小角 $\mathrm{X}$ 線散乱による分析から逆ミセル の界面に可溶化することが示唆されており ${ }^{6,7)}$, 本研究で観察された過剩な水の可溶化挙動之対応 すると考えられる.

一方, 逆ミセル有機相に正抽出されたリボヌク レアーゼAの円偏光二色性 (CD) 分析を行うと, 水相中とは異なるスペクトルを示し, 立体構造の 変化を伴って逆ミセルに抽出・可溶化されている ことがわかる ${ }^{5)}$. しかしながら，その変化は顕著 でなく，親水的なリボヌクレアーゼ A は, より バルク水相に近い環境であるウオーター・プール 内に可溶化されていると考えられる(Fig.6(b) $)^{5)}$. リボヌクレアーゼ A が逆ミセルのウオーター・ プールに可溶化された場合, 界面は拡大されず, 過剩な水の可溶化は観測されなかったと考えられ

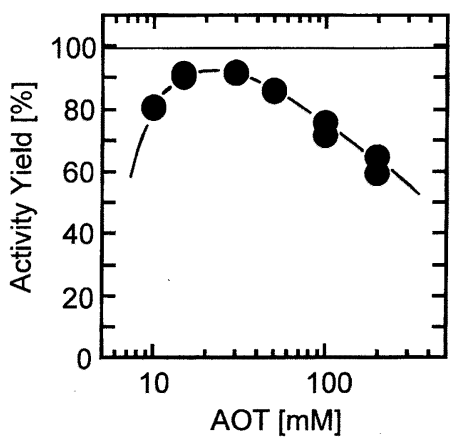

Fig. 8 Effect of AOT concentration on the recovered activity yield of cytochrome $c$ after forward and backward extractions.

る.

\section{5. タンパク質の活性収率に対する AOT 濃度の影響}

酵素などのバイオ生産物は, 希薄な濃度で生産 され，また，活性を有するものが多い，従って， 分離操作を経て得られる目的物質の活性之回収率 が重要となる. そこで, AOT 逆ミセルを利用し てタンパク質の正・逆抽出操作を行い, 得られた 活性収率に対する両親媒性分子 AOT 濃度の影響 を検討した。

正抽出と逆抽出を行った後に回収されたシトク ロム $c$ の反応活性は, いずれの AOT濃度におい ても，ほぼ $100 \%$ 保持されていた ${ }^{8)}$ 。 シトクロム cの CD スペクトルを Fig. 7 に示した. 正抽出 を行う前の水相中のスペクトルと, 逆ミセル有機 相に抽出されたシトクロム $c$ のスペクトルとを比 較すると, 著しく変化していることがわかる ${ }^{8)}$. この結果, シトクロム $c$ は構造の変化を伴って逆 ミセル有機相に正抽出・可溶化されていることが わかる. 前述した様に, シトクロム $c$ は逆ミセル 界面の AOT 分子膜に入り込むかたちで可溶化し ていると考えられ，その状態ではAOT 分子と強 く相互作用し構造が変化したものと考えれる.

しかしながら, 水相に逆抽出すると初期水相中 と同じスペクトルを示し, 逆抽出を行うとタンパ 
ク質がリフォールディングし水相中でのネイティ ブな構造に回復することがわかった.この結果は, 正・逆抽出操作後の反応活性が, ほぼ $100 \%$ 保持 されていた結果と対応している.

リボヌクレアーゼ A の場合にも，僅かな構造 変化を伴って逆ミセル有機相に正抽出されたが, 水相に逆抽出すると構造を回復し, 初期水相中と 同等の活性を示した ${ }^{5)}$. 正・逆抽出率と相対活性 の積として求められるシトクロム $c$ の活性収率に 対する AOT 濃度の影響を Fig. 8 に示した ${ }^{8)}$. 活性収率は, $\mathrm{AOT}$ 濃度に対して極大を示し, 至 適な AOT 濃度が存在した. 低 AOT 濃度側, お よび, 高 $\mathrm{AOT}$ 濃度側での活性收率の低下は，そ れぞれ正抽出と逆抽出の際の抽出率の低下が原因 であった。

\section{6. おわりに}

逆ミセルを利用したタンパク質の抽出分離法 は，工業的な実用化をめざす分離操作であるとい う観点から, 今後もより効率的な操作条件を明ら かにしていくと共に, 新規な機能を付与した逆ミ セル系を構築していくことが必要であろう.特に, バイオセパレーションに利用するためには, 生体 適合性の高い逆ミセル系の開発と, バイオアフィ 二ティーなどを導入した選択性の向上が必要であ ると考え検討を進めている ${ }^{9,10)}$.

逆ミセルは, 幾多の分子が自己組織化した分子 集合体である.このため，種々の機能を持った分 子を導入し，目的に沿った分子集合体の設計が可 能になるものと期待される. そのためには, 逆ミ セルの界面に形成される両親媒性分子の分子膜と これに内包されるウオーター・プール，そしてタ ンパク質などの可溶化物質との相互作用を系統的 に明らかにし，機能性分子集合体の設計の基礎を 集積していくことが重要であると考えている.

\section{謝 辞}

この度は, 1997 年度日本膜学会研究奨励賞を睗り, 学会長をはじめとする諸先生方, ならびに諸先輩方に
篤くお礼申し上げます，身に余る栄誉とそれに伴う今 後の責務の重さを実感しております。本研究を進める に際し, 温かくご指導いただいた古崎新太郎先生, 清 水賢先生，今井正直先生には，心からお礼申しあげる とともに，深く感謝致します．また，分子集合体に関 する研究を発展的に導いていただいた中嶋光敏先生, 佐野洋先生, 鍋谷浩志先生に深く感謝致します。さら には，共に研究を行った同空の諸氏に篤くお礼申し上 げます. 皆様のご指導, 御協力なしに本研究は成し得 なかったものと痛感しております．有り難うございま した. 今後とも, 膜学の発展に寄与できるよう微力な がら力を尽くしていきたいと思います，ご指導ご鞭撻 の程，よろしくお願い申し上げます。

\section{文 献}

1）市川創作, 古崎新太郎 :「新タンパク質応用工学」, 籏野昌弘監修, p.547-555, フジテクノシステム (1996)

2) Ichikawa S, Imai M, Shimizu M : Biotechnol. Bioeng., 39 20-26, (1992).

3) Imai $M$, Natsume $T$, Naoe $K$, Shimizu $M$, Ichikawa S, Furusaki S : Bioseparation, 6 325-333, (1997).

4) Fisher H. F. : Biochemistry, 51 1285-1291, (1964).

5) Ichikawa S, Hattori N, Furusaki S : "Value Adding Through Solvent Extraction”, Shallcross D C, Paimin R, Prvcic L M eds., p. 1423-1428, The University of Melbourne (1996).

6) Pileni M P, Zemb T, Petit C : Chem. Phys. Lett., 118 414-420, (1985).

7) Adachi M, Harada M : J. Phys. Chem., 97 3631-3640, (1993).

8) Ichikawa S, Furusaki S : Trans. IChemE., 73 33-39, (1995).

9）市川創作, 杉浦慎治, 中嶋光敏, 佐野洋, 関 実, 古崎新太郎：日本膜学会第 19 年会講演要旨集, p.96, (1997).

10) Ichikawa S, Koyama K, Seki M, Nakajima M, Sano Y, Kameyama M, Nagata T, Furusaki S : Proceedings of The 1996 International Congress on Membranes \& Membrane Processes, p.682-683, (1996).

（受付 1997 年 9 月 30 日 掲載決定 10 月 2 日） 